\title{
Policy Study and Stunting Prevention in Surabaya
}

\author{
Queen Khoirun Nisa Mairo ${ }^{1}$, Sherly Jeniawaty ${ }^{1}$ \\ ${ }^{1}$ Lecturer, Department of Midwifery Health Polytechnic Health Ministry Surabaya, Indonesia
}

\begin{abstract}
Background: Nutritional Status Survey in 2017 showed prevalence of stunting toddlers in Indonesia was still high, which was $29,6 \%$ above the limitation determined by WHO $(20 \%) .{ }^{8}$ Conducted study by Ricardo in Bhutta in 2013 stated that stunting toddler contributed against 1,5 million (15\%) of toddler mortality in the world and caused 55 millions of children had lost their healthy life time every year. ${ }^{2}$ Result of Basic health research (Riskesdas) in 2013 stated that condition of consuming food for pregnant woman and toddlers in 2016-2017 showed in Indonesia, 1 from 5 pregnant women was malnutrition. Decrease of stunting rate only reached 4\% in 1992 until 2013. Presidential Regulation number 42/2013 had determined National Movement of First Thousand Days of Life for increasing toddler's nutritional status that was followed by development program, including its budget. ${ }^{7}$

Method: This research was mix method research, which was a step in the research by combining two kinds of approaches, qualitative and quantitative. Besides, this research utilized gradual mix technique. Population in this research was Public Health Centers in Surabaya area. Meanwhile, the sample was all of policyholders in Surabaya, who were Head of Public Health Centers and midwives. This research utilized data analysis in gradual qualitative-quantitative. Not conflict of interest, source of funding self and ethical clearance taken from committee ethic.Hence, the analysis was conducted on qualitative data, then, it was followed by quantitative data.
\end{abstract}

Result and Analysis: Public Health Center of Pucang Surabaya still had the highest stunting rate among 10 Public Health Centers. Public Health Center of Tanah Kali Kedinding Surabaya had quite high increasing rate against stunting from 2017 until 2018. Almost all programs were appropriate with 1000 HPK (1000 first day of life) guidelines in area of Public Health Centers Surabaya that had been done by the midwives. According to FGD result, regulation and policies which were related to $1000 \mathrm{HPK}$, particularly for regulation of exclusive breast milk and PMBA which had been quite many either in was statute law, Government Regulation, Minister of Health Regulation, Decree of Minister of Health, or Regional Regulation. Handling stunting was done by synergy among central government, regional government, entrepreneur and community organization. High commitment from all health professions was much needed so that it could be able to hasten the decrease of stunting.

Conclusion and Suggestion: the implementation of 1000 HPK program had been conducted as an effort in reducing stunting rate. However, stunting problem still had not been solved. Therefore, it was needed cooperation mutually in cross sector for handling stunting problem, particularly in Surabaya City, East Java Province, Indonesia.

Keywords: Prevention Stunting, Policy Study, Surabaya.

\section{Introduction}

Nutritional Status Survey (PSG)) 2017 showed prevalence of stunting toddlers in Indonesia was still high, which was $29,6 \%$ above the limitation determined by WHO $(20 \%)$. Conducted research by Ricardo in
Bhutta in 2013 stated that stunting toddlers contributed against 1,5 million $(15 \%)$ of toddler mortality in the world and caused 55 millions of children had lost their healthy life time every year. ${ }^{2}$ Prevalence of stunting in Indonesia has quite stagnant rate from 2007 until 
2013. ${ }^{6}$ WHO determined that limitation of nutrition problem was not more than $20 \%$, thus, Indonesia was a country that had health problem for society. ${ }^{5}$ Moreover, this research aimed at studying the policy and gaps that could be solved through policy option which was through analyzing legal document and other literature and programs that had been developed. Then, it was conducted discussion form by involving experts in composing result as the policy option. ${ }^{1}$

\section{Material and Method}

This research was mix method research, which was a step of research by combining two kinds of approaches, qualitative and quantitative. Population in this research was Public Health Centers in Surabaya. Meanwhile, the sample was all of policyholders in Surabaya area, who were Head of Public Health Center and midwives. This research utilized data analysis in gradual qualitativequantitative. Hence, the analysis was conducted on qualitative data, then, it was followed by quantitative data.
Findings: Respondents in this research were midwives which the result of basic health research (Riskesdas) in 2018 showed that the decrease of stunting prevalence in National level was in $6,4 \%$ for 5 years period, from $37,2 \%$ (2013) to be $30,8 \%$ (2018). Meanwhile, for toddlers who had normal status increased from $48,6 \%$ (2013) to be $57,8 \%$ (2018). Meanwhile, the other toddlers suffered other nutrition problems. ${ }^{5}$

Description of Stunting in Surabaya: Result of Nutritional Status Survey in 2017, stunting in Surabaya was $10,78 \%$, meanwhile, in 2018 , it decreased to be 8,92 $\%$. Research result for stunting data in 10 Public Health Centers in Surabaya in 2017 and 2018 as followed:

Description of Stunting Survey based on 1000 HPK program in Public Health Center: Surabaya is a city that implements 1000 HPK (1000 first day of life) program with good survey. In 10 Public Health Centers through midwives who had responsibility either in the inside or outside of the Public Health Center, it was obtained the result below:

Table 1. Description of Stunting Survey based on 1000 HPK program in Public Health Center

\begin{tabular}{|c|c|c|c|c|}
\hline & \multicolumn{2}{|c|}{ Done } & \multicolumn{2}{|c|}{ Undone } \\
\hline & $\Sigma$ & $\%$ & $\Sigma$ & $\%$ \\
\hline \multicolumn{5}{|l|}{ Intervention of Specific Nutrition on Pregnant Woman Group } \\
\hline Supplementation of iron folate & 78 & 86,67 & 12 & 13,33 \\
\hline Reducing cigarette consumption and air pollution in house & 56 & 62,22 & 34 & 37,78 \\
\hline Giving additional food for pregnant woman who was chronic less energy & 74 & 82,22 & 16 & 17,78 \\
\hline Overcoming pregnant woman who suffered from intestinal worm & 68 & 75,55 & 22 & 24,44 \\
\hline Calcium supplementation for pregnant woman & 78 & 86,67 & 12 & 13,33 \\
\hline \multicolumn{5}{|l|}{ Intervention of specific nutrition on group of 0-6 months old Baby } \\
\hline Breast feeding promotion (individual and group counseling) & 74 & 82,22 & 16 & 17,78 \\
\hline \multicolumn{5}{|l|}{ Intervention of specific nutrition on group of $7-23$ months old Toddler } \\
\hline Breast feeding promotion (individual and group counseling) & 74 & 82,22 & 16 & 17,78 \\
\hline Communication of behavior changes for improving in giving complementary feeding & 70 & 77,78 & 20 & 22,22 \\
\hline Zinc supplementation & 72 & 80,00 & 18 & 20,00 \\
\hline Zinc for diarrhea management & 69 & 76,67 & 21 & 23,33 \\
\hline Vitamin A supplementation & 86 & 95,55 & 4 & 4,44 \\
\hline Giving iodine salt & 75 & 83,33 & 15 & 16,67 \\
\hline Preventing acute malnutrition & 68 & 75,55 & 22 & 24,44 \\
\hline Giving anthelmintic drug & 86 & 95,55 & 4 & 4,44 \\
\hline Iron fortification and supplementation activity & 80 & 88,89 & 10 & 11,11 \\
\hline
\end{tabular}




\begin{tabular}{|c|c|c|c|c|}
\hline & \multicolumn{2}{|c|}{ Done } & \multicolumn{2}{|c|}{ Undone } \\
\hline & $\Sigma$ & $\%$ & $\Sigma$ & $\%$ \\
\hline \multicolumn{5}{|l|}{ Intervention of sensitive nutrition } \\
\hline Providing clean water & 66 & 73,33 & 24 & 26,67 \\
\hline $\begin{array}{l}\text { Food security and nutrition (giving additional food for pregnant woman who was chronic } \\
\text { less energy }\end{array}$ & 71 & 78,89 & 19 & 21,11 \\
\hline Birth limitation & 63 & 70,00 & 27 & 30,00 \\
\hline Health insurance & 60 & 66,67 & 30 & 33,33 \\
\hline Basic childbirth insurance & 60 & 66,67 & 30 & 33,33 \\
\hline Food fortification (vitamin A supplement) & 71 & 78,89 & 19 & 21,11 \\
\hline $\begin{array}{l}\text { Nutrition education for society (breast feeding promotion through individual and group } \\
\text { counseling) }\end{array}$ & 72 & 80,00 & 18 & 20,00 \\
\hline Intervention for female teenagers & 63 & 70,00 & 27 & 30,00 \\
\hline
\end{tabular}

Almost all programs which were appropriate with 1000 HPK guideline in Public Health Centers in Surabaya had been conducted by the midwives.

Description of Informant's Characteristic: Informant who participated in this research were 10 informants with varied characteristic. This research was conducted in Public Health Centers in Surabaya area and Public Health Office of Surabaya. This research was conducted in Public Health Center of Dupak, Public Health Center of Jagir, Public Health Center of Krembangan Selatan, Public Health Center of Tanah Kali Kedingding, Public Health Center of Mulyorejo, Public Health Center of Siwalan Kerto, Public Health Center of Gunung Anyar, Public Health Center of Sidotopo and Public Health Center of Sidotopo Wetan. Meanwhile, the informant was the policy maker and stunting program implementer in each agency.

\section{Result of Structured Interview Analysis:}

Analysis of regional regulation system in Surabaya: Every regulation that was conducted based on the policy, the regulation that was related to stunting was Government Regulation (PP) number 33/2012 about exclusive breast milk, Presidential Regulation number 42/2013 about national movement to accelerate nutrition improvement, planning guideline of national movement to accelerate nutrition for first thousand days of life or 1000 HPK movement had begun since 2013. Besides, it was also appropriate with planning of regional construction in chapter 260, chapter 261 and chapter 262 regarding stunting that was appropriate with planning of national construction, it was coordinated, synergized and harmonized by Regional Development Planning Agency (BAPPEDA) in Province level. It was also appropriate with 5 pillars of handling stunting, particularly in pillar 2 about national campaign and communication of behavior changes of communication strategy for behavior of stunting prevention and also there was a facility of stunting policy in regulation of minister of home affairs (permendagri) number 22/2018 about Regional Development Work Plan (RKPD) in 2019.

Analysis of Fund Source in Stunting Prevention Program in Surabaya: Analysis of fund source from central DIPA about technical orientation of neonatal maternal health, antenatal based on standards, SDIDTK, MTBS, SN-PKPR and Kespro catin etc., fund source from central DIPA about implementation of government matters that became regional authority which was funded by and at the expense of Regional development budget (APBD). ${ }^{7}$

Stunting Fund Allocation Policy: Fund allocations of stunting prevention program were nutrition intervention, maternal and child health service, environment health, pregnant mother and 0-2 years old child, or household of 1.000 HPK. Effort in increasing the effectiveness from several initiative and program/ activity through support from national leadership, priority decision and harmonization of this program needed coordination and technical support, high-level advocacy and cross-sectoral partnerships to accelerate target of nutrition improvement for society which was expected by focusing on nutrition improvement on first 1000 days 
of life. ${ }^{6}$ The policy maker and program implementer of cross sector had a power to improve the future through developing the intervention of sensitive nutrition that impacted on optimization of either individual nutrition or country. Furthermore, beginning to invest as soon as possible could result better human resource, break the poverty circle and increase economic development. However, the main goal was synergizing to break the cycle of nutrition problem for the improvement of future generation. Concerning with quite wide opportunity for effort in improving human resource against the impact of trans-generation, recently, Indonesia strengthened more the coordination from several sides.

Support for Allocation of Stunting Funds: Support for allocation of stunting funds facilitated regional government in internalizing SPM in regional development planning documents (RPJMD/RKPD), facilitated regional government in prioritizing SPM in budgeting documents (APBD), conducted a training and monitoring for implementation of government matters, facilitated the publication of Citizenship Registration Number (NIK) and newborn baby certificates.

Purpose of policy for special allocation funds (DAK) was in physique TA 2019 and as we knew that, DAK in physique was fund that was allocated in regional development budget (APBN) to certain region for donating physical certain activity which was regional matters and it was appropriate with national priority, such as providing basic public service infrastructure and facilities, both for fulfilling minimum service standard $(S P M)$ and reaching either national priority or accelerating regional construction and region with certain characteristic for overcoming the differences in public services among regions.

Obstruction in Stunting Fund Allocation: Obstruction in stunting fund allocation was such as coordination in implementing intervention of either specific or sensitive nutrition, regulation that was related to handling stunting which had not been become as a general base for handling stunting, the access in implementing intervention of specific and sensitive nutrition still had not been integrated, it had not been optimal campaign of dissemination that was related to stunting. Besides, another obstruction was the regency/city was still late in fulfilling requirements for disbursement of funds. In addition, the requirements were making report of convergence of stunting prevention in regency level in previous fiscal year.
Regulation of Stunting Prevention Program against SPM: Regulation of stunting prevention program against SPM was managed by central policy of SPM PP number 2 in 2018 SPM, policy and regulation which were related to stunting was statute law (UU) number 36/2009 about health, UU number 18/2012 about food, RPJMN 2015-201. Moreover, it was needed synchronization of central and regional activities for regulation. ${ }^{6}$

Related Policy with 1000 HPK: Related policy with 1000 HPK in Surabaya was conducted breast milk village program, companion donor "Towards Platinum City of Surabaya", in English was "going toward the platinum generation of Surabaya" for prospective bride and groom class.

Legality Component Program: Legality componen program, such as decree of work for Head of service, for Public Health Center had not been from the regency/ city or from the Public Health Center itself, but there were the instruments in implementing program, such as SPM, regulation of minister of health (Permenkes) and Standard Operating Procedure (SOP) of Public Health Center, using Permenkes of 21 years in 2016 about the use of JKN Capitation Fund.

FGD Analysis: The implementation of Focus Group Discussion was conducted on Saturday, $7^{\text {th }}$ September 2019 about policy study and stunting prevention in Surabaya and the respondents were 10 respondents. From the FGD analysis above, it was obtained policy study about policy of 1000 HPK which was there and it had been conducted, but the cooperation in cross society had not been occurred, synergy was between institute of central government and regional government and education institute. All of activities in society inserted with campaign for reducing stunting. After being conducted Focus Group Discussion (FGD) analysis, it was obtained policy recommendations:

Synergy of program between Central Government and Regional Government in overcoming stunting.

Monitoring about the implementation of 1000 HPK by society.

Commitment of human resources for implementation in overcoming stunting in all sectors.

\section{Discussion}

Stunting was related to poverty. Concerning with 
stunting toddlers was not only occurred on low/poor family, but also on middle/high family. Between poverty and stunting was like a vicious circle. ${ }^{3}$

The poverty made nutritional adequacy in underprivileged families unfulfilled, thus, the malnourished pregnant mother would give birth the malnourished baby and stunting. Moreover, stunting toddlers who could not be intervened for first 1.000 days of life would grow up and have less productive and low quality of life. ${ }^{4}$

Result of Nutritional Status Survey in 2017, stunting in Surabaya was $10,78 \%$, meanwhile in 2018 , it was $8,92 \%{ }^{6}$ Policy of Presidential Regulation in 42/2013 about national movement to accelerate the nutritional improvement focused on rescuing first thousand days of life (1000 HPK) for stunting. In 2015, Surabaya selected to publish the policy of maternal and children safety. This research aimed at analyzing the rescue policy of 1000 HPK and decrease of stunting in Surabaya.

The success of nutrition improvement was a sequel from the success in food supply sector, behavior changes and the increase of knowledge, environment improvement and clean water facility supply, providing employment and the increase of income and also other various determinant factors. In line with it, handling nutrition problem could not only been conducted by government, but it also needed involvement and support from others, such as development partners, nongovernmental organization, universities, professional organization and community organization. Hence, let's cooperate to improve nutrition condition for Indonesian toddlers. We are in Ministry of People's Welfare will do coordination to all activities which are done either by government or non-government in improving nutrition for society.

From quantitative data, it was seen that first sequence for stunting problem was seen in Public Health Center of Pucang $(20,27 \%)$ and this rate had been below national target, that was $28 \%$., which meant that it had been success to reduce stunting rate from cumulative percentage. However, if it was seen from the increase in previous year, it was known that in the average, it did not increase significantly. This was because most of Public Health Centers here had conducted the activity of 1000 HPK program.

More over, stunting was correlated with poverty. Nevertheless, case of stunting toddlers was not only occurred on low/poor family but also on middle/high family. In other word, it was like a vicious circle between poverty and stunting. The poverty made nutritional adequacy in underprivileged families unfulfilled, thus, the malnourished pregnant mother would give birth the malnourished baby and stunting. Moreover, stunting toddlers who could not be intervened for first 1.000 days of life would grow up and have less productive and low quality of life.

\section{Conclusion and Suggestion}

The implementation of 1000 HPK program had been conducted as an effort in reducing stunting rate. However, stunting problem still had not been solved. Therefore, it was needed cooperation mutually in cross sector for handling stunting problem, particularly in Surabaya City, East Java Province, Indonesia.

Ethical Clearence: Taken from Health Polytechnic Health Ministry Surabaya committee.

\section{Source of Funding: Self}

\section{Conflict of Interest: Nil.}

\section{References}

1. Black et al. Maternal And Child Undernutrition: Global And Regional Exposures And Health Consequences. The Lancet Series. 2008. Available from : www.thelancet.com

2. Black, Robert E, CesarG Victora, Susan $P$ Walker,Zulfi qar A Bhutta, Parul Christian, Mercedes de Onis,Majid Ezzati,Sally GranthamMcGregor, Joanne Katz, Reynaldo Martorell, Ricardo Uauy and Maternal and Child Nutrition Study Group $†$. 2013.” Maternal and child undernutrition and overweight in low- income and middle-income countries." The lancet.

3. Darity, W. A. Stunted Growth. Detroit Macmillan References USA. 2008. International Encylopedia of The Social Sciences, 2 nd Edition. $8:$ 187- 89.

4. Gigante et al. Epidemiology Of Early And Late Growth In Height, Leg And Trunk Length: Findings From A Birth Cohort Of Brazilian Males. European Journal of Clinical Nutrition 2009 : 375-381.

5. Kemenkes RI. Laporan Riset Kesehatan Dasar. Jakarta: Balai Penelitian dan Pengembangan Kesehatan Kementrian Kesehatan RI, 2018. 
6. Kemenkes RI. Cegah Stunting dengan Perbaikan Pola Makan, Pola Asuh dan Sanitasi, Kementrian Kesehatan RI, 2018.

7. Kemenkes, RI. Buku Saku Jakarta: Pemantauan Status Gizi, Kementerian Kesehatan RI, 2017.
8. WHO. Complementary feeding family foods for breasged children. 2000 (cited 25 Desember 2014). Available from: whqlibdoc.who.int/hq/2000/who nhd_00.1.pdf. 